\title{
COMPARATIVE PROFITABILITY OF BORO RICE AND POTATO PRODUCTION IN SOME SELECTED AREAS OF MYMENSINGH DISTRICT
}

\author{
S. Ahmed1, M. H. A. Rashid ${ }^{2}$ and N. Chowdhury ${ }^{2}$ \\ Department of Agricultural Economics, Bangladesh Agricultural University \\ Mymensingh-2202, Bangladesh
}

\begin{abstract}
This study was undertaken to determine and compare the profitability of Boro rice and potato production. In total 60 farmers of which 30 Boro rice growers and 30 potato growers were selected randomly from four villages of Gouripur Upazila in Mymensingh district. Descriptive as well as statistical analysis were done to achieve the objectives of the study. The Cobb-Douglas production function was used to determine the effects of individual inputs on Boro rice and potato production. The major findings of the study were that the cultivation of Boro rice and potato was profitable from the view point of farmers. The per hectare total return from Boro rice and potato were Tk. 83,320.00 and Tk. 2,62,625.22 respectively. The gross cost of Boro rice and potato production were Tk. 54,202.74 and 1,20,221.71 respectively. Again the net return from Boro rice and potato were Tk. 24,117.26 and 1,42,403.51 respectively. The Benefit Cost Ratio (BCR) was 1.41 and 2.18 respectively for Boro rice and potato production. The results indicated that potato production was more profitable than Boro rice production. It was also evident from the study that per hectare net returns were influenced by most of the factors included in model.
\end{abstract}

Key words : Profitability, Boro rice, Potato

\section{INTRODUCTION}

Bangladesh is a country dominated by agriculture. The combined contribution of all sub sectors of agriculture (crop, livestock, forestry and fisheries) to GDP is 21.77 per cent. The crop sub sector alone contributes 12.19 per cent to GDP (Bangladesh Economic Review, 2006). Rice is a staple food and potato is an important cash crop for farmers in the SubTropical Eastern Indo-Genetic Plains of India and Bangladesh (Anon, 2004-2005). In Bangladesh, the rice area is about 10 million hectare and 75 per cent of the total area of agricultural crops and 93 per cent of the total area planted to cereals. The rice production is by far the most important provider of rural employment (HIES 2005 and BBS 2006).

1 Post-graduate students, Department of Agricultural Economics, Bangladesh Agricultural University Mymensingh-2202, Bangladesh

2 Professor and Lecturer, respectively, Department of Agricultural Economics, Bangladesh Agricultural University Mymensingh-2202, Bangladesh 
Potato is one of the important cash crops in Bangladesh as its added value to agricultural sector is about Tk. 44016 million in 2007 - 08 (BBS, 2007). Potato is an important and leading staple crop of the world and occupied topmost position after rice and wheat in respect of production consumption (Akhter et al., 1998). It is an important vegetable crop for cash income. The production of vegetables including roots and tubers in our country is low so that per capita availability is about 13 per cent of the total requirements (Saha, 2005). Prominent argument for giving more attention to the production of non-rice crops are that these have the potentials to improve not only the nutritional status but also improve soil fertility that is being depleted due to mono-culture with rice (Biswas and Sarkar 1987; Bhuiyan 1989 and Mirnada 1989). The yield of irrigated HYV Boro rice has increased significantly over the past years (BBS 2006), but rice is one of the most costly crops, the return from HYV Boro rice has declined because of low market price and high cost of production. Therefore, the present study was designed to estimate relative costs and returns of producing Boro rice and potato.

\section{MATERIALS AND METHODS}

The study was conducted at Gouripur upazila of Mymensingh district in 2009. Data for the present study were collected from the selected farmers of four villages namely: Bhagnabari, Chorkalibari, Chornilaikha, Rupnakandi under Gouripur upazila in Mymensingh district. In total 60 farmers of which 30 Boro rice growers and 30 potato growers were selected randomly. The following algebric equation was developed to asses the costs and returns of Boro rice and potato production.

$\mathrm{GRi}=\sum_{i=1}^{n} Q_{m i} P_{m i}+\sum_{i=1}^{n} Q_{b i} P_{b i}$

Where,

$\mathrm{GR}_{\mathrm{i}}=$ Gross return from $\mathrm{i}^{\text {th }}$ product $(\mathrm{Tk} / \mathrm{ha})$

$\mathrm{Q}_{\mathrm{mi}}=$ Quantity of the $\mathrm{i}^{\text {th }}$ main product $(\mathrm{kg} / \mathrm{ha})$

$P_{m i}=$ Average price of the $i^{\text {th }}$ main product $(\mathrm{Tk} / \mathrm{kg})$

$\mathrm{Q}_{\mathrm{bi}}=$ Quantity of the $\mathrm{i}^{\text {th }}$ by product $(\mathrm{kg} / \mathrm{ha})$

$\mathrm{P}_{\mathrm{bi}}=$ Average price of the $\mathrm{i}^{\text {th }}$ by product $(\mathrm{Tk} / \mathrm{kg})$

i $\quad=1,2,3, \ldots \mathrm{n}$

Net return was calculated by deducting all costs (variable and fixed) from gross return. To determine the net return of Boro rice and potato production the following equation was used in the present study:

$\pi=P y Y-\sum_{i=1}^{n}\left(P_{x i} X_{i}\right)-T F C$

Where,

$\Pi \quad=$ Net return $(\mathrm{Tk} / \mathrm{ha})$

$\mathrm{P}_{\mathrm{y}} \quad=$ Per unit price of the product $(\mathrm{Tk} / \mathrm{kg})$ 
$\mathrm{Y} \quad=$ Quantity of the product per hectare $(\mathrm{kg})$

$\mathrm{P}_{\mathrm{xi}} \quad=$ Per unit price of $\mathrm{i}^{\text {th }}$ inputs (Tk)

$\mathrm{X} \mathrm{i}=$ Quantity of the $\mathrm{i}^{\text {th }}$ inputs per hectare $(\mathrm{Kg})$

$\mathrm{TFC}=$ Total fixed cost $(\mathrm{Tk})$

$\mathrm{i} \quad=1,2,3, \ldots, \mathrm{n}$ (number of inputs).

To determine the contribution of variable inputs to the production of Boro rice and potato, Cobb-Douglas form of regression equation was employed:

$Y=a X_{1}^{b_{1}} X_{2}^{b_{2}} X_{3}^{b_{3}} X_{4}^{b_{4}} X_{5}^{b_{5}} X_{6}^{b_{6}} X_{7}^{b_{7}} X_{8}^{b_{8}} X_{9}^{b_{9}} e^{u_{i}}$

By taking log on both sides the Cobb-Douglas production function was transferred to the following logarithmic form because it could be solved by the ordinary least squares (OLS) method.

$\ln Y=\ln a+b_{1} \ln X_{1}+b_{2} \ln X_{2}+b_{3} \ln X_{3}+b_{4} \ln X_{4}+b_{5} \ln X_{5}+b_{6} \ln X_{6}+b_{7} \ln X_{7}++b_{8} \ln X_{8}+b_{9} \ln X_{9}+U_{i}$

Where,

$\mathrm{Y}=$ gross return $(\mathrm{Tk} / \mathrm{ha})$

$\mathrm{X}_{1}=$ costs of seed $(\mathrm{Tk} / \mathrm{ha})$

$\mathrm{X}_{2}=$ costs of human labour (Tk/ha)

$\mathrm{X}_{3}=$ costs of animal power (Tk/ha)

$\mathrm{X}_{4}=$ costs of power tiller (Tk/ha)

$\mathrm{X}_{5}=$ costs of Urea $(\mathrm{Tk} / \mathrm{ha})$

$\mathrm{X}_{6}=$ costs of TSP $(\mathrm{Tk} / \mathrm{ha})$

$\mathrm{X}_{7}=$ costs of $\mathrm{MP}(\mathrm{Tk} / \mathrm{ha})$

$\mathrm{X}_{8}=$ costs of insecticides $(\mathrm{Tk} / \mathrm{ha})$

$\mathrm{X}_{9}=$ costs of irrigation $(\mathrm{Tk} / \mathrm{ha})$

a $=$ constant $/$ intercept $(\mathrm{Tk} / \mathrm{ha})$

$b_{1}, b_{2}, \ldots b_{9}=$ coefficients of respective variables

$\mathrm{U}_{\mathrm{i}} \quad=$ Error term

In $=$ Natural logarithm

\section{RESULTS AND DISCUSSION}

Relative profitability of Boro rice and potato production is presented in Table 1. It is observed that per hectare total value of Boro rice and potato production were Tk. $82,320.00$ and Tk. 2,62,625.22 respectively. Gross cost of Boro rice and potato production were Tk. 58,202.74 and Tk. 1,20,221.71 respectively. Net returns of Boro rice and potato production were Tk. 24,117.26 and Tk. 1,42,403.51 respectively. The undiscounted benefit cost ratios of Boro rice and potato were 1.41 and 2.18 respectively. It is evident from the Table 1 that potato production was more profitable than Boro rice production in the study area. 
Table 1. Per hectare yield, costs and returns Boro rice and potato production

\begin{tabular}{lcc}
\hline \multicolumn{1}{c|}{ Particulars } & Boro rice & Potato \\
\hline Yield (kg) & 6,000 & 16,302 \\
Price (Tk/kg) & 13.50 & 16.11 \\
Value of product (Tk) & 81,000 & $2,62,625.22$ \\
Value of by product (Tk) & 1,320 & - \\
Gross return (Tk) & 82,320 & $2,62,625.22$ \\
Variable cost (Tk) & $42,917.8$ & $1,07,188.99$ \\
Fixed cost (Tk) & $15,284.94$ & $13,032.72$ \\
Gross cost (Tk) & $58,202.74$ & $1,20,221.71$ \\
Gross margin (Tk) & $39,402.2$ & $1,55,436.23$ \\
Net margin (Tk) & $24,117.26$ & $1,42,403.51$ \\
BCR (undiscounted) & 1.41 & 2.18 \\
\hline
\end{tabular}

Source : Ahmed (2009)

Table 2. Estimated values of the coefficients and related statistics of Cobb-Douglas production function of Boro rice and potato

\begin{tabular}{|c|c|c|c|c|}
\hline \multirow[t]{2}{*}{ Exploratory variables } & \multicolumn{2}{|c|}{ Boro rice } & \multicolumn{2}{|c|}{ Potato } \\
\hline & $\begin{array}{c}\text { Values of } \\
\text { coefficients }\end{array}$ & t-value & $\begin{array}{c}\text { Values of } \\
\text { coefficients }\end{array}$ & $\mathrm{t}$-value \\
\hline Intercepts & 19029.133 & 1.588 & 50874.894 & \\
\hline Seeds $\left(X_{1}\right)$ & $1.898^{*}$ & 4.165 & $1.218^{* *}$ & 2.426 \\
\hline Human labour $\left(X_{2}\right)$ & $-0.780^{* *}$ & -2.382 & 0.010 & 0.026 \\
\hline Animal power $\left(X_{3}\right)$ & - & - & 0.047 & -0.163 \\
\hline Power tiller $\left(\mathrm{X}_{4}\right)$ & -0.145 & -0.238 & -0.525 & -4.026 \\
\hline Urea $\left(X_{5}\right)$ & 0.192 & 0.565 & -0.042 & -0.417 \\
\hline $\operatorname{TSP}\left(X_{6}\right)$ & $0.356^{* * *}$ & 1.820 & $-0.789^{* *}$ & -2.895 \\
\hline $\operatorname{MP}\left(X_{7}\right)$ & -0.082 & -0.547 & $-0.525^{*}$ & -4.026 \\
\hline Insecticides $\left(X_{8}\right)$ & -0.078 & -0.654 & $0.824^{\star * *}$ & 2.053 \\
\hline Irrigation $\left(X_{9}\right)$ & -0.676 & -0.1357 & - & - \\
\hline $\mathrm{R}^{2}$ & 0.787 & & 0.851 & \\
\hline Adjusted R2 & 0.706 & & 0.794 & \\
\hline F-value & 9.702 & & 14.994 & \\
\hline Sample size & 30 & & 30 & \\
\hline
\end{tabular}

Source : Field survey 2009, * Significant at 1 per cent level, ** Significant at 5 per cent level, *** Significant at 10 per cent level 
It is evident from Table 2 that the value of the coefficients of multiple determination $\left(\mathrm{R}^{2}\right)$ were 0.787 and 0.851 for Boro rice and potato respectively which means that the explanatory variables included in the model explained 78.7 and 85.1 per cent of total variation in Boro rice and potato production respectively.

The measure of the overall fit of the estimated regression, F-value of all the cases were highly significant at 1 per cent level, implying that the variables significantly explained the variation in returns of Boro rice and potato production.

The explanatory variables were human labour, seed, power tiller, fertilizer, insecticides and irrigation for Boro rice production and human labour, seed, animal power, power tiller, fertilizer and insecticides for potato production. In case of Boro rice, estimated values of the relevant coefficient revealed that among the included variables, seed and TSP showed positive and significant effect, human labour showed negative but significant effect. For potato production, estimated values of the relevant coefficient revealed that among the included variables, seed, pesticides showed positive and significant effect, TSP and MP showed significant but negative effect on gross return.

\section{CONCLUSION}

It is evident from the results of the present study that both Boro rice and Potato production in the study areas were profitable. Potato production is more profitable than Boro rice. It revels that there has been an ample scope for the farmers to increase their income by practicing this sort of non-rice crops.

\section{REFERENCES}

Ahmed, S. 2009. A Comparative Economic Study of Boro rice and Potato Production in Some Selected Areas of Mymensingh District. Unpublished, M. S. Thesis, submitted to the Department of Agricultural Economics, Bangladesh Agricultural University, Mymensingh.

Akhter, M. E. M. S., Ali, Z. N., Huq, A. K. M. A., Habib, M. A. and Hossain, A. B. S. 1998. Granula, Cleopatra and Binella New Potato Varieties in Bangladesh, Prog. Sci., 24(1): 133-143.

Anonymous. 2004-2005. Agricultural Statistics at a Glance. Ministry of Agriculture, Government of India.

Bangladesh Economic Review 2006. Economic Advisors Wing Finance Division, Ministry of Finance, Government of the People's Republic of Bangladesh.

BBS 2006. Statistical Yearbook of Bangladesh. Bangladesh Bureau of Statistical Division. Ministry of Planning. Government of the People's Republic of Bangladesh.

BBS 2007. Statistical Yearbook of Bangladesh. Bangladesh Bureau of Statistics, Statistical Division. Ministry of Planning. Government of the People's Republic of Bangladesh.

Bhuyian, S. I. 1989. Irrigation and Water Management for Diversified Cropping in Rice Irrigation Management Network Paper, 89/1C. 
Biswas, M. R. and Sarkar, R. I. 1987. Crop Diversication with Existing Irrigation Management : A Challenge in Bangladesh. Irrigation Management for Diversified Cropping.

HIES, 2005. Reports on Household Income and Expenditure Survey, Ministry of Planning, Dhaka, Bangladesh.

Mirnada, S. M. 1989. Irrigation Management for Crop Diversification in Indonesia, Philippines and Sri Lanka. A Synthesis of IIMI Research Technology, Colombo, Sri Lanka.

Saha, P. K. 2005. A Comparative Economic Study of Wheat, Potato and Groundnut Production in Rowmari Thana of Kurigram District. Unpublished, M. S. Thesis, submitted to the Department of Agricultural Economics, Bangladesh Agricultural University, Mymensingh. 